variation in the size of the beetles as the largest may weigh five or six times as much as the smallest.

\title{
CONTROL
}

Fumigation with carbon bisulphide is the common method of control. If one has only a small quantity of beans to treat he may not wish to use this method. The bean weevil in all its stages may be killed by heat without injuring the beans. The embryos are killed in 10 minutes at $52^{\circ}$ C.; newly hatched larvæ, in 7 minutes at $55^{\circ}$; full grown larvæ in beans, in 20 minutes at $55^{\circ}$; pupæ in beans, in 25 minutes at $55^{\circ}$; and adults in 4 minutes at $55^{\circ}$. In practice these short exposures will not be sufficient but the length of treatment must vary with the quantity of beans and the type of receptacle. It required nine hours for the center of two quarts of beans enclosed in a tight paper bag to reach the surrounding temperature of $55^{\circ} \mathrm{C}$. The seed should be spread openly in shallow layers and subjected to a temperature of $55^{\circ}$ for about an hour. According to the investigations of others the germinating power is not injured at this temperature. The bean weevil will not breed at cold temperatures. It would be a good practice to place beans in cold storage or to expose them to the cold winter weather.

President C. Gordon Hewitr: The last paper on the program will be given by Mr. I. W. Davis.

\section{THE PRESENT STATUS OF THE GIPSY AND BROWN-TAIL MOTHS IN CONNECTICUT}

By Inving W. Davis, New Haven, Conn.

The gipsy moth of Europe was first taken in Connecticut in Stonington, which lies in the southeastern corner of the state, in July, 1905, when Mr. Ernst Frensch, an amateur collector, caught two female moths. This was not reported, however, until March, 1906, when it became known through correspondence between Doctor Britton and Mr. Frensch. Scouts were immediately employed, who determined the extent of the infestation, which contained less than a square mile of territory, and control measures were practised. This work was continued from that time until 1914, but no trace of the pest was found from 1911-1913, and the windspread of that year, which infested several towns in the eastern end of the state, is now believed to have caused this reinfestation. 
Late in the year 1909 a colony of gipsy moths was located at Wallingford, about fifteen miles north of the city of New Haven, and a force of men under Mr. D. J. Caffrey (now of the Bureau) began the work of extermination: This work was done very thoroughly and although over 8,000 egg-clusters were destroyed that first winter, at the end of four years no trace of the moth was found. The scouting, however, was carried on for two years thereafter.

Following the discovery of five gipsy moth caterpillars at the Stonington infestation in the summer of 1913, a force of Federal scouts was sent to Connecticut, and during that winter found ten towns along the eastern border of the state slightly infested with this pest. None of these localities contained any old egg-clusters, and it is,' therefore, believed that the spread occurred during the spring of that year. In the winter of 1914 this area was again scouted, together with the territory just to the west of the infestations, and ten more towns were found infested, but as before the infestations were light, in many cases only a few egg-clusters being found in a town. In the fall of 1915 on account of increased appropriations, the state was able to put more men in the field than formerly, although the Federal men still scouted the outside towns. During that winter one new town was found to contain the gipsy moth, making a total of 21 towns which together have an area of about seven hundred and thirty square miles. Five towns, however, where the moth had been taken in previous years were found free of the pest, and the number of colonies was greatly reduced.

Wherever egg-clusters have been found, they have been soaked with creosote, and in the larger infestations all underbrush has been cut and burned. Tanglefoot bands are applied the following spring to all trees, including and within 100 feet of the infested trees. In 1916, 13,165 such bands were applied. Sixty of the larger infestations, especially those showing caterpillars, were sprayed in June with arsenate of lead.

The heaviest infestations at the present time are in the northeastern corner of the state with scattering colonies south to the coast but in no locality have they been found in sufficient numbers to cause any noticeable injury. The largest colonies have consisted of 400 egg-clusters, but only two such have been found. The scouting work which has been done thus far this winter gives evidence of another, but shorter, windspread than that of 1913 , for in the northeastern corner of the state a large number of infestations have been found which contain but a single egg-cluster each, and there is a marked falling off in these as the work is carried westward.

The brown-tail moth was first found in Connecticut at Thompson 
in the spring of 1910, and as in the case of the gipsy moth, the heaviest infestations have been confined to the northeastern corner of the state. During the winter of 1910-1911 several towns in this section were scouted and a total of 7,133 winter webs were destroyed. Since that time the winter scouting has been continued, and at present there are 72 of the 168 towns in the state that are within the quarantined area.

The last legislature passed a law which provided that the towns were to do the moth work within their limits, whenever the state entomologist should deem it necessary, and through this means four towns, namely, Putnam, Thompson, Woodstock, and Pomfret were scouted in the winter of $1915-1916$ and a total of over 14,000 webs were destroyed. It has also been our practice to have the towns bordering the infested district scouted, and if these are found to be infested, to scout to the west until no evidence of the pest was found. During the last two years no new towns have been added, and a marked decrease in the number of webs in the border towns has been noticed.

Some of the towns in the older infested areas have been examined this. winter to ascertain the seriousness of the infestations, but so few webs. have been noticed, that it is doubtful if it will be necessary to require. any of the towns to do that work this winter.

(At the close of the business session, which has already been reported, the meeting adjourned.)

A. F. Burgess, Secretary

\section{Meeting of Section on Apiary Inspection}

The Section met in the American Museum of Natural History, New York, December 27, 1916. The following persons were in attendance.

E. G. Carr, New Egypt, N. J.; E. F. Phillips, Washington, D. C.; Franklin Sherman, Jr., Raleigh, N. C.; George H. Rea, Raleigh, N. C.; C. S. Bukurth, New Brunswick, N. J.; George A. Dean, Manhattan, Kansas; H. B. Hungerford, Manhattan, Kansas; Frank C. Pellett, Atlantic, Iowa; E. N. Cory, College Park, Maryland; James S. Hine, Columbus, Ohio; Max Kisliuk, Jr., Columbus, Ohio; Charles A. Weigel, Columbus, Ohio; G. W. Underhill, West Raleigh, N. C.; H. Spencer, West Raleigh, N. C.; J. A. Manter, Storrs, Conn.; P. T. Barnes, Harrisburg, Pa.; H. E. Backus, North East, Pa.; J. G. Sanders, Harrisburg, Pa.; E. D. Ball, Madison, Wis.; George G. Atwood, Albany, N. Y.; A. F. Burgess, Melrose Highlands, Mass.; B. N. Gates, Amherst, Mass.; T. J. Headlee, New Brunswick, N. J.

A number of interesting papers, published elsewhere in this report, were given and generally discussed by those present. 